\title{
Evaluation of the Relationship Between the Breeder's Age, Breed and the Incubator Types on Quality and Animal Welfare in the Hatchery
}

Original Article

\section{Euthor(s)}



Avian Pathology Laboratory, College of Veterinary Medicine and Animal Science (FMVZ - UNESP), Department of Clinical Veterinary Medicine, Botucatu, SP, Brazil.

Departamento of Zootecnia (UFPR), Palotina, 85950-000, Paraná, Brazil.

Laboratory of Biotecnology (UFPR), Palotina 85950-000, Paraná, Brazil.

Iv Agricultural Supervisor, JBS Company, Dourados, 79804970, Mato Grosso do Sul, Brazil.

College of Veterinary Medicine (UFPR), Veterinary Hospital, Palotina, 85950-000, Paraná, Brazil.

\section{Mail Address}

Corresponding author e-mail address Camila de Souza Oro

Rua professor Doutor Walter Maurício Correia, Botucatu, Paraná - 18618-681,

Brasil.

Phone: +55 (14) 3880-2073

Email: camila.oro@unesp.br

\section{-Keywords}

Embryos. Hatch. Poultry.

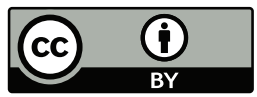

Submitted: 03/February/2019

Approved: 14/June/2019

\section{ABSTRACT}

About 33.3\% of chicken life is conditioned by the result of embryonic development. Therefore, understanding and improving the early phase of the broiler's life is critical to guarantee their well-being. Thus, the objective of this research was to evaluate the relationship between the breeder's age, breed and the incubator types on quality and animal welfare in the hatchery. The experimental design was completely randomized in a $2 \times 2 \times 3$ factorial arrangement (incubator, breed and age), with 12 treatments and 6 replicates each. The eggs derived of Cobb 500 and Ross's breeders at the beginning of the laying period, middle age and at the end of the laying period. It is concluded that the size of the eggs is related to the breeder's age and breed, which influences directly the number of bled eggs. In addition, well-being in the hatchery can be affected by decreased hatching and contamination that is higher in older breeders. Cobb eggs also need more attention because they are larger, therefore, they have a higher risk of breakage and they are more sensitive to the low concentration of $\mathrm{CO}_{2}$ at the hatcher.

\section{INTRODUCTION}

About $33.3 \%$ of chicken life is conditioned by the result of embryonic development. Therefore, understanding and improving the early phase of the broiler's life is critical to guarantee their well-being.

Preferably, between 17 days and 6 hours up to 18 days and 5 hours of incubation, in egg vaccination may be performed (Fernandes et al., 2016), during the moment of transference from the incubators to the hatchers. This type of vaccination has several advantages, among them: the reduction of the stressful response associated with the procedures of post-hatch vaccination and precision of the inoculation.

However, when the needle, by unknown factors, reaches the embryo (which the incubation specialists call of bled eggs) instead of the amniotic fluid, even if the immunization happened, there will be damage to the embryo's well-being, since at this stage of embryonic development there is already sensitivity to painful stimuli (Marasco et al., 2012).

Another obstacle to ensuring well-being in the hatchery is insufficient egg weight loss. The oxidation of the lipids present in the yolk produces metabolic water that must be gradually lost, allowing the entrance of oxygen into the air chamber and consequently the embryo peeling and the transition to lung breathing (Dos Santos, 2014).

Hypoxia due to low egg weight loss, results in the increase of the internal and external pip and the increase of plasma corticosterone levels in chicks affecting their quality and even their yield in the field (Rodricks et al., 2006). However, high egg weight loss may also lead to dehydration of the embryo (Molenaar et al., 2010) or malabsorption of the yolk. Therefore, factors that interfere with moisture loss should be controlled to ensure the well-being of the embryo. 
Therefore, the objective of this research was to evaluate the relationship between the breeder's age, breed and the incubator on quality and animal welfare in the hatchery. Through the counting of bled eggs in the transference of the eggs from the incubators to the hatchers and through the evaluation of the egg weight loss with 18 days, chick yield weight loss and embryoticmortality.

\section{MATERIALS AND METHODS}

This project was approved by the Ethics Committee on the Use of Animals of the UFPR, Sector Palotina city (CSSA / Palotina) under protocol n. 19/2017. The experiment was carried out in November 2017 in a commercial hatchery. The origin of the eggs was the farm of the same cooperative (company).

The parameters used in the incubation during the experiment were:

- Multiple stageincubator: $98,7^{\circ} \mathrm{F}$ and $83 \% \mathrm{RH}$

- Multiple stagehatcher trays: $98,5^{\circ} \mathrm{F}$ and $84 \% \mathrm{RH}$

- Single stageincubator: $100.5^{\circ} \mathrm{F}-97.4^{\circ} \mathrm{F}, 70 \%$ $40 \%$ RH e 10000 - 3500 ppm of CO2

- Single stagehatcher trays: $98,2^{\circ} \mathrm{F}-96,0{ }^{\circ} \mathrm{F}, 68 \%$ - 40\% RH 4000 - 3200 ppm of CO2.

The experimental design was completely randomized in a $2 \times 2 \times 3$ factorial arrangement (incubator, breed and age), totaling 12 treatments with 6 replicates each. Each cart inside the incubators was considered as an experimental unit with 5040 eggs, totaling 36 carts for each incubator (single stage and multiple stage incubators). The eggs derived by Cobb 500 and Ross's breeders at the beginning of the laying period (until 30 weeks of age); between 40 and 45 weeks of age (middle age); and at the end of the laying period (more than 60 weeks of age).

At the time of transfer of the eggs to the hatchers and in egg vaccination the quantity of eggs that were bled per cart (Figure 1) was recorded.

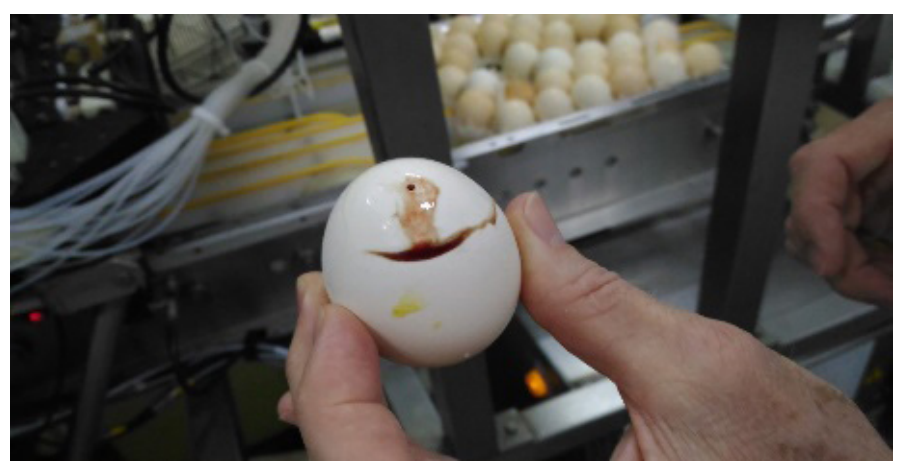

Figure 1 - Bled eggs that were accounted after in-eggs vaccination.
To evaluate the percentage of the egg weight loss, initially 84 eggs were collected randomly from the incubation cart (experimental unit) in the egg room and then placed in two trays to be weighed. Finally, the trays were weighed and identified.

At 18 days of incubation, at the time of the eggs transfer, the same trays were weighed again. The weight of the eggs was divided by the initial weight of the eggs, multiplied by 100 and subtracted from 100 to obtain the eggs weight loss percentage. In total, egg weight loss percentage of 504 eggs per treatment totaling 6048 eggs was evaluated.

After hatching, for the evaluation of hatching percentage, the total number of chicks hatch was counted. A sample of 168 chicks was weighed to evaluate the chick yield weight loss percentage and the value found was divided by the initial weight of the eggs. For this, the trays with the eggs were identified on arrival at the hatchery and at the time of transfer to the hatcher. In total, 1008 chicks per treatment were used, totaling 12,096 chicks.

After hatching, one sample of eggs that did not hatch per carton, were collected to evaluate the embryonic mortality. In total, 504 eggs per treatment were evaluated, totaling 6048 eggs. These eggs were classified as: 0 to 3 days, 4 to 10 days, 11 to 17 days, 18 to 21 days, contaminated and internal/external pip.

Each dependent variable was compared between the treatments by means of the Analysis of variance (ANOVA), triple factor, followed by Tukey's test. Once the samples were selected by means of a completely randomized design, it was decided to perform the parametric analysis assuming that the data were in normality. The analyzes were performed by SAS 9.0 (Statistical Analysis System), using a level of significance of $p<0.05$.

\section{RESULTS AND DISCUSSION}

There were interactions between breed $x$ incubator, breed $\mathrm{x}$ breeder's age and incubator $\mathrm{x}$ breeder'sage in relation to eggs bled ( $p<0.05$; table 1$)$.

In the unfolding (Table 2) of the interactions between the factors, it was possible to observe that the number of bled eggs was higher, mainly in eggs from Cobb's old breeders, incubated in incubators of multiple stage and when originated from Ross's young breeders, incubated in a single-stage incubator.

The vaccine that reaches the embryo (bled eggs) cause pain to the embryo, since at this stage of 
embryonic development sensitivity to the pain stimulus already occurs (Marasco et al., 2012).

Early exposure to increased stress levels may have a later effect on increased mortality, decreased development, greater stress sensitivity, and change behavior of chicks. In addition, corticosterone in egg injections in broiler eggs showed higher concentrations of corticosterone from broilers when stressed at 64 days, demonstrating the potentially longer lasting effect of early stressors (Marasco et al., 2012).

Bled eggs may have a connection with the size of the eggs that is closely related to the breeder's age and breed. Eggs from the Ross's young breeder tend to be smaller. The Cobb's old breeder eggs tend to be larger. When the egg sizes deviate from the normal distribution curve in which the vaccination machine is regulated, a higher number of bled eggs and vaccine error probably occurs.

Due to the scarce literature on bled eggs, new studies should be carried out to also understand the contribution of the incubator in the quantity of bled eggs and this way, establish a strategy to avoid the suffering of the embryo, either by uniformizing the size of the eggs or in new regulations on vaccination for different egg sizes.

Table 1 - Values (average \pm standard deviation) relating to the bled eggs were derived by young $(Y)$, middle-age $(\mathrm{M})$, old (O), Cobb and Ross breeders incubated in multiplestage (ME) and single-stage (SS).

\begin{tabular}{|c|c|c|c|}
\hline Breed & Incubator & breeder's age & Bled eggs \\
\hline \multirow[t]{6}{*}{ Ross } & \multirow[t]{3}{*}{ ME } & $Y$ & $3,00 \pm 2,19$ \\
\hline & & M & $6,17 \pm 2,86$ \\
\hline & & $\mathrm{O}$ & $4,67 \pm 2,94$ \\
\hline & \multirow[t]{3}{*}{ SS } & Y & $14,33 \pm 6,38$ \\
\hline & & M & $4,67 \pm 3,01$ \\
\hline & & O & $7,50 \pm 2,95$ \\
\hline \multirow[t]{6}{*}{ Cobb } & \multirow[t]{3}{*}{$\mathrm{ME}$} & Y & $5,17 \pm 2,64$ \\
\hline & & M & $8,00 \pm 5,66$ \\
\hline & & O & $14,33 \pm 6,12$ \\
\hline & \multirow[t]{3}{*}{ SS } & Y & $4,50 \pm 1,87$ \\
\hline & & M & $5,50 \pm 3,94$ \\
\hline & & O & $9,83 \pm 4,45$ \\
\hline \multicolumn{2}{|c|}{$p$-value of interation } & & $<.0001$ \\
\hline \multicolumn{2}{|l|}{ Breed } & & 0.2246 \\
\hline \multicolumn{2}{|c|}{ Incubator } & & 0.3843 \\
\hline \multicolumn{2}{|c|}{ Breeder's age } & & 0.0316 \\
\hline \multicolumn{2}{|c|}{ Breed x Incubator } & & 0.0007 \\
\hline \multicolumn{2}{|c|}{ Breed $\times$ Breeder's age } & & 0.0004 \\
\hline \multicolumn{2}{|c|}{ Incubator x Breeder's age } & & 0.0053 \\
\hline \multicolumn{2}{|c|}{ Breed $x$ Incubator $x$ Breeder's age } & & 0.0682 \\
\hline
\end{tabular}

Table $\mathbf{2}$ - The unfolding of the triple interaction between breed $\mathrm{x}$ breeder's age $\mathrm{x}$ incubator and values (averages) relating to the bled eggs were derived by young $(Y)$, middle-age (M), old (O), Cobb and Ross breeders incubated in multiple-stage (ME) and single-stage (SS).

\begin{tabular}{|c|c|}
\hline The Bled Eggs & \\
\hline \multicolumn{2}{|l|}{ Breed x Breeder's Age } \\
\hline Interaction & Value of $p$ \\
\hline O x breed & 0.0092 \\
\hline Cobb $\mathrm{x}$ breeder's age & $<0.001$ \\
\hline \multicolumn{2}{|l|}{ Old breeder } \\
\hline Breed & Averages \\
\hline Cobb & $12.08^{\mathrm{A}}$ \\
\hline Ross & $6.08^{B}$ \\
\hline \multicolumn{2}{|l|}{ Cobb } \\
\hline breeder's age & Averages \\
\hline Y & $4.83^{\mathrm{B}}$ \\
\hline M & $6.75^{\mathrm{B}}$ \\
\hline O & $12.08^{A}$ \\
\hline \multicolumn{2}{|l|}{ Breed $x$ Incubator } \\
\hline Interaction & Valueof P \\
\hline ME $x$ breed & 0.0075 \\
\hline Ross $\mathrm{x}$ incubator & 0.0097 \\
\hline \multicolumn{2}{|l|}{ ME } \\
\hline Breed & Averages \\
\hline Cobb & $9.16^{A}$ \\
\hline Ross & $4.61^{\mathrm{B}}$ \\
\hline \multicolumn{2}{|l|}{ Ross } \\
\hline Incubator & Averages \\
\hline SS & $8.83^{A}$ \\
\hline ME & $4.61^{\mathrm{B}}$ \\
\hline \multicolumn{2}{|c|}{ Breeder's Age $x$ Incubator } \\
\hline Interaction & Value of $\mathrm{P}$ \\
\hline ME $x$ breeder's age & 0.0364 \\
\hline $\mathrm{Yx}$ incubator & 0.0188 \\
\hline \multicolumn{2}{|l|}{$\mathrm{ME}$} \\
\hline breeder's age & Averages \\
\hline Y & $4.08^{B}$ \\
\hline M & $7.08^{A B}$ \\
\hline O & $9.5^{\mathrm{A}}$ \\
\hline \multicolumn{2}{|l|}{ Young breeder } \\
\hline Incubator & Averages \\
\hline SS & $9.41^{\mathrm{A}}$ \\
\hline ME & $4.08^{\mathrm{B}}$ \\
\hline
\end{tabular}

$A, B$ - Different capital letters in the columns indicate statistical difference by the Tukey test $(p<0.05)$; Equal letters not differ significantly between themselves.

It was observed that there was no effect ( $p>0.05)$ of the breeder's age, breed and incubator on the percentage of egg weight loss with 18 days and chick yield weight loss (Table 3).

The non-significance of the factors studied probably is result of a good management in the different types of incubator, which supplied the different types of eggs needs, allowing better well-being during all the 
Table 3 - Values (average \pm standard deviation) relating to egg weight loss, chick yield weight loss and hatching percentage were derived by young (y), middle-age ( $\mathrm{m})$, old (o), cobb and ross breeders incubated in multiple-stage (me) and single-stage (ss).

\begin{tabular}{|c|c|c|c|c|c|}
\hline Breed & Incubator & Breeder's age & $\%$ Eggweightloss & $\%$ Chickyieldweightloss & $\%$ Hatching \\
\hline \multirow[t]{6}{*}{ Ross } & ME & $\mathrm{Y}$ & $9.84 \pm 0.88$ & $71.41 \pm 2.95$ & $85.96 \pm 1.59$ \\
\hline & & M & $10.78 \pm 1.76$ & $70.44 \pm 3.55$ & $88.75 \pm 0.64$ \\
\hline & & $\mathrm{O}$ & $10.74 \pm 0.72$ & $71.31 \pm 2.30$ & $68.20 \pm 15.77$ \\
\hline & SS & Y & $9.86 \pm 0.21$ & $71.06 \pm 1.04$ & $90.23 \pm 0.22$ \\
\hline & & M & $9.90 \pm 0.84$ & $71.65 \pm 0.91$ & $86.36 \pm 0.35$ \\
\hline & & O & $10.55 \pm 1.16$ & $70.28 \pm 1.47$ & $66.79 \pm 16.11$ \\
\hline \multirow[t]{6}{*}{ Cobb } & $\mathrm{ME}$ & Y & $10.86 \pm 0.86$ & $69.96 \pm 1.38$ & $84.19 \pm 2.14$ \\
\hline & & M & $10.08 \pm 1.07$ & $69.93 \pm 2.01$ & $89.48 \pm 1.26$ \\
\hline & & $\mathrm{O}$ & $11.21 \pm 0.69$ & $69.75 \pm 1.49$ & $72.13 \pm 3.57$ \\
\hline & SS & Y & $10.25 \pm 0.35$ & $71.37 \pm 1.69$ & $89.31 \pm 2.55$ \\
\hline & & M & $9.96 \pm 0.87$ & $72.33 \pm 1.35$ & $88.46 \pm 2.21$ \\
\hline & & $\mathrm{O}$ & $10.96 \pm 0.95$ & $70.70 \pm 1.24$ & $81.46 \pm 2.87$ \\
\hline \multicolumn{2}{|c|}{$p$-value of interation } & & 0.1138 & 0.4386 & $<.0001$ \\
\hline \multicolumn{2}{|l|}{ Breed } & & & & 0.055 \\
\hline \multicolumn{2}{|c|}{ Incubator } & & & & 0.1518 \\
\hline \multicolumn{2}{|c|}{ Breeder's age } & & & & $<0.001$ \\
\hline \multicolumn{2}{|c|}{ Breed x Incubator } & & & & 0.1807 \\
\hline \multicolumn{2}{|c|}{ Breed x Breeder's age } & & & & 0.0236 \\
\hline \multicolumn{2}{|c|}{ Incubator x Breeder's age } & & & & 0.2095 \\
\hline \multicolumn{2}{|c|}{ Breed x Incubator x Breeder's age } & & & & 0.369 \\
\hline
\end{tabular}

phases of hatching. In addition, studies that evaluated the effect of the breed (Santos et al., 2009; Almeida et al., 2006) and the breeder's age (Tanure et al., 2009; Rocha et al., 2008; Silva et al. 2016) on egg weight loss also did not observe a significant difference as in the present research.

There was connection between breed $\mathrm{x}$ breeder's age $(p<0.05)$ on the percentage of hatching. In the unfolding of the connection (Table 4), independent of the breed the old breeder showed to have worse hatching. When the breeder's middle age was evaluated, Ross's breed obtained worse hatching.

Campos (2000) and Barbosa et al. (2015) have observed that as the breeder's age increase, their eggs tend to hatch less. The cause is the thickness of the shell. The thickness of the shell less than $0.27 \mathrm{~mm}$, found in old breeders, hardly keeps the embryo alive until the end of the incubation cycle, the best result is obtained with shell of thickness between 0.33 and $0.35 \mathrm{~mm}$ (Schmidt et al., 2003). The shell acts in the nutrition and protection of the embryo against physical and biological agents and when this function is reduced, the damage to the well-being occurs, since it can result in the death of the embryo.

However, Ross's breed eggs tend to hatch less than Cobb's breed eggs because the fertility of Ross's rooster decrease in middle age (Baião et al., 2012), and this factor is not related with the well-being in the hatchery.
Table 4 - The unfolding of the triple interaction between breed $x$ breeder's agex and values (averages) relating to hatching percentage were derived by young $(Y)$, middleage $(\mathrm{M})$, old (O), Cobb and Ross breeders incubated in multiple-stage (ME) and single-stage (SS).

\begin{tabular}{lc}
\hline$\%$ Hatching - Breed x Breeder's Age & \\
\hline Interaction & Value of $p$ \\
Cobbxbreeder's age & $<0.0001$ \\
Rossxbreeder's age & $<0.0001$ \\
Mxbreed & 0.0398 \\
\hline Cobb & \\
\hline Breeder's age & Averages \\
$Y$ & $86.75^{\mathrm{A}}$ \\
$M$ & $88.96^{\mathrm{A}}$ \\
$O$ & $76.79^{\mathrm{B}}$ \\
\hline Ross & \\
\hline Breeder's age & Averages \\
$Y$ & $88.09^{\mathrm{A}}$ \\
$M$ & $87.55^{\mathrm{A}}$ \\
$O$ & $67.49^{\mathrm{B}}$ \\
\hline Middle-agebreeder & \\
\hline Breed & Averages \\
Cobb & $88.09^{\mathrm{A}}$ \\
Ross & $87.95^{\mathrm{B}}$ \\
\hline
\end{tabular}

$A, B$ - Different capital letters in the columns indicate statistical difference by the Tukey test $(p<0.05)$; Equal letters not differ significantly between themselves.

There was no significant effect of the breeder's age, breed and incubator ( $p>0.05$ ) on the embryonic death in any of the ages evaluated on (Table 5).

Embryonic death can be caused by several factors depending on the embryonic stage that it occurs. 
Table 5 - Values (average \pm standard deviation) relating to embryonic mortality were derived by young $(y)$, middle-age $(m)$, old (o), cobb and ross breeders incubated in multiple-stage (me) and single-stage (ss).

\begin{tabular}{|c|c|c|c|c|c|c|}
\hline Breed & Incubator & Breeder's age & 0 to 3 & 4 to 10 & 11 to 17 & 18 to 21 \\
\hline \multirow[t]{6}{*}{ Ross } & $\mathrm{ME}$ & $Y$ & $8.17 \pm 2.79$ & $3.50 \pm 2.88$ & $2.33 \pm 1.21$ & $5.00 \pm 3.10$ \\
\hline & & M & $11.50 \pm 9.35$ & $4.67 \pm 5.35$ & $5.00 \pm 5.10$ & $5.00 \pm 6.96$ \\
\hline & & 0 & $13.50 \pm 11.33$ & $5.17 \pm 4.54$ & $3.17 \pm 3.43$ & $3.33 \pm 3.67$ \\
\hline & SS & Y & $3.83 \pm 2.93$ & $2.00 \pm 2.10$ & $2.83 \pm 3.13$ & $2.83 \pm 1.83$ \\
\hline & & M & $5.33 \pm 6.38$ & $1.83 \pm 1.72$ & $2.67 \pm 2.73$ & $2.67 \pm 3.39$ \\
\hline & & 0 & $11.33 \pm 13.09$ & $4.83 \pm 4.31$ & $8.67 \pm 9.09$ & $3.17 \pm 5.38$ \\
\hline \multirow[t]{6}{*}{ Cobb } & $\mathrm{ME}$ & Y & $9.33 \pm 9.87$ & $2.67 \pm 1.21$ & $4.67 \pm 1.63$ & $2.17 \pm 4.40$ \\
\hline & & M & $4.83 \pm 4.17$ & $1.50 \pm 1.64$ & $2.83 \pm 1.33$ & $2.67 \pm 4.13$ \\
\hline & & $\mathrm{O}$ & $6.67 \pm 6.22$ & $2.00 \pm 1.90$ & $2.33 \pm 1.75$ & $2.17 \pm 3.43$ \\
\hline & SS & Y & $7.17 \pm 9.20$ & $1.33 \pm 1.51$ & $4.00 \pm 3.46$ & $3.33 \pm 2.07$ \\
\hline & & M & $7.17 \pm 6.74$ & $2.50 \pm 2.74$ & $5.00 \pm 5.06$ & $3.00 \pm 3.16$ \\
\hline & & O & $11.33 \pm 10.48$ & $2.33 \pm 2.66$ & $4.67 \pm 4.68$ & $3.00 \pm 3.90$ \\
\hline$p$-value & & & 0.6366 & 0.2977 & 0.3588 & 0.9785 \\
\hline
\end{tabular}

There are few researches that relate the breeder's age (Procksch \& Freitas, 2018), the breed and the type of incubator with the embryonic death in a specific phase. According to Procksch \& Freitas (2018), this decrease in hatching does not occur due to mortality at any specific age, as it occurred in the present research.

There was a significant effect of breeder's age, breed and incubator $(p<0.05$ tab.6) and interaction between incubator $x$ age $(p<0.05)$ on contaminated eggs. In the unfolding of the interaction (Table 7), it was observed that contaminated eggs were more frequent when originating from the old breeder and when incubated in the single-stage machine.

The physical environment of a hatchery, due to high temperature and humidity, is ideal for the survival of pathogenic microorganisms that can be introduced through contaminated eggs.

The contamination is more common in the multistage machine because it is always in use, without the possibility of emptying and disinfecting, besides the constant flow of the carts (Gonzales, 2011). However, as the present research demonstrated, the single-stage machine can also maintain greater contamination in the incubator if cleaning and disinfection are not done properly and if contaminated eggs are incubated in this incubator.

The breeder's feces is the main source of eggs contamination, which tend to be more affected when they originate from the old breeder due to the increase in pore diameter in this type of egg (Carvalho et al., 2007).

This contamination, depending on the intensity and the agent involved, can impair the embryo's well-being, due to the inferior development and possible increase of mortality, even in the field, besides reducing the sanity of the lot.

Table 6 - Values (average \pm standard deviation) relating to contaminated eggs were derived by young $(\mathrm{y})$, middle-age $(\mathrm{m})$, old (o), Cobb and Ross breeders incubated in multiplestage (me) and single-stage (ss).

\begin{tabular}{|c|c|c|c|}
\hline Breed & Incubator & $\begin{array}{c}\text { Breeder's } \\
\text { age }\end{array}$ & Contaminated eggs \\
\hline \multirow[t]{6}{*}{ Ross } & ME & $\mathrm{Y}$ & $0.00 \pm 0.00$ \\
\hline & & M & $0.17 \pm 0.41$ \\
\hline & & 0 & $0.50 \pm 1.22$ \\
\hline & SS & Y & $0.17 \pm 0.41$ \\
\hline & & M & $0.17 \pm 0.41$ \\
\hline & & O & $1.67 \pm 1.51$ \\
\hline \multirow[t]{6}{*}{ Cobb } & $\mathrm{ME}$ & Y & $0.00 \pm 0.00$ \\
\hline & & M & $0.00 \pm 0.00$ \\
\hline & & O & $0.17 \pm 0.41$ \\
\hline & SS & Y & $0.33 \pm 0.82$ \\
\hline & & M & $0.17 \pm 0.41$ \\
\hline & & 0 & $2.50 \pm 2.35$ \\
\hline \multicolumn{2}{|c|}{$p$-value of interaction } & & 0.0002 \\
\hline \multicolumn{2}{|l|}{ Breed } & & 0.7103 \\
\hline \multicolumn{2}{|c|}{ Incubator } & & 0.0029 \\
\hline \multicolumn{2}{|c|}{ Breeder's age } & & 0.0001 \\
\hline \multicolumn{2}{|c|}{ Breed $x$ Incubator } & & 0.2673 \\
\hline \multicolumn{2}{|c|}{ Breed x Breeder's age } & & 0.8309 \\
\hline \multicolumn{2}{|c|}{ Incubator x Breeder's age } & & 0.0057 \\
\hline \multicolumn{2}{|c|}{ Breed x Incubator x Breeder's age } & & 0.5757 \\
\hline
\end{tabular}

There was a significant effect of the breeder's age, breed and incubator and interaction of the breed and incubator on the amount of live/dead internal and external pip ( $p<0.05$, tab 8). In the unfolding (Table 9), the Cobb eggs presented higher numbers of pecked eggs when incubated in the single-stage incubator. 
Oro CS, De Souza FEZ, Rodrigues WC, Oro JS, Guirro ECBP
Evaluation of the Relationship Between the Breeder's Age, Breed and the Incubator Types on Quality and Animal Welfare in the Hatchery
Table 7 - The unfolding of the triple interaction between breeder age $\mathrm{x}$ incubator and values (averages) relating to contaminated eggs were derived by young $(Y)$, middle-age $(\mathrm{M})$, old (O), Cobb and Ross breeders incubated in multiplestage (ME) and single-stage (SS).

\begin{tabular}{lc}
\hline Contaminated Eggs - Incubator x Breeder's Age & \\
\hline Interaction & Value of $p$ \\
SSxbreeder's age & 0.0004 \\
Oxincubator & 0.0092 \\
\hline SS & \\
\hline Breeder's age & Averages \\
Y & $0.25^{\mathrm{B}}$ \\
M & $0.16^{\mathrm{B}}$ \\
O & $2.08^{\mathrm{A}}$ \\
\hline Old breeder & \\
\hline Incubator & Averages \\
SS & $2.08^{\mathrm{A}}$ \\
ME & $0.33^{\mathrm{B}}$ \\
\hline
\end{tabular}

$A, B$ - Different capital letters in the columns indicate statistical difference by the Tukey test $(p<0.05)$; Equal letters not differ significantly between themselves.

Live/dead internal and external pip usually occur due to the large hatch window or management errors at the hatcher trays such as excessive fumigation and temperature, humidity and gas exchange inadequacy.

Barbosa et al. (2015) reported that approximately on the 19th day of incubation, the need for oxygen increases, and respiration by diffusive transport exerted by chorioallantoid cannot meet this requirement, which stimulates the embryo to the internal pecking and hatching.

Therefore, in order to guarantee chick welfare at hatching, a slight increase in $\mathrm{CO}_{2}$ concentration and a decrease in $\mathrm{O}_{2}$ concentration should be provided (O'Dea et al., 2004; Hamidu et al., 2007; Bamelis et al., 2008).

In the multiple-stage incubator, ventilation participates in the machine's cooling system, not removing the gases as efficiently as the single-stage incubator, and increasing the $\mathrm{CO}_{2}$ concentration inside the incubator (Gonzales, 2011). Thus, the single stage machine has a more efficient ventilation system. The reduction of $\mathrm{CO}_{2}$ level at birth increases the number of internal and external pip as occurred in the present research. However, this type of incubator can be manipulated for best result, since it allows to work with different levels of $\mathrm{CO}_{2}$.

Baracho et al. (2010) also observed that the incidence of internal and external pip was influenced by the high air velocity and the low $\mathrm{CO}_{2}$ concentration, which negatively affected the Cobb eggs like this research.
Table 8 - Values (average \pm standard deviation) relating to Internal and external pip were derived by young (y), middle-age $(\mathrm{m})$, old (o), cobb and ross breeders incubated in multiple-stage (me) and single-stage (ss).

\begin{tabular}{|c|c|c|c|}
\hline Breed & Incubator & Breeder's age & Internal and external pip \\
\hline \multirow[t]{6}{*}{ Ross } & \multirow[t]{3}{*}{ ME } & Y & $1.67 \pm 1.21$ \\
\hline & & M & $1.67 \pm 1.21$ \\
\hline & & $\mathrm{O}$ & $1.33 \pm 0.82$ \\
\hline & \multirow[t]{3}{*}{ SS } & Y & $1.17 \pm 1.33$ \\
\hline & & M & $1.00 \pm 0.89$ \\
\hline & & 0 & $2.17 \pm 2.56$ \\
\hline \multirow[t]{6}{*}{ Cobb } & \multirow[t]{3}{*}{$\mathrm{ME}$} & Y & $0.00 \pm 0.00$ \\
\hline & & M & $2.17 \pm 1.33$ \\
\hline & & 0 & $0.50 \pm 0.84$ \\
\hline & \multirow[t]{3}{*}{ SS } & Y & $2.33 \pm 1.37$ \\
\hline & & M & $2.67 \pm 1.21$ \\
\hline & & O & $1.83 \pm 1.72$ \\
\hline \multicolumn{3}{|c|}{$p$-value of interaction } & 0.0389 \\
\hline \multicolumn{3}{|l|}{ Breed } & 0.7926 \\
\hline \multicolumn{3}{|c|}{ Incubator } & 0.0473 \\
\hline \multicolumn{3}{|c|}{ Breeder's age } & 0.3056 \\
\hline \multicolumn{3}{|c|}{ Breed $x$ Incubator } & 0.0206 \\
\hline \multicolumn{3}{|c|}{ Breed $x$ Breeder's age } & 0.0823 \\
\hline \multicolumn{3}{|c|}{ Incubator x Breeder's age } & 0.2713 \\
\hline \multicolumn{3}{|c|}{ Breed $\mathrm{x}$ Incubator $\mathrm{x}$ Breeder's age } & 0.3056 \\
\hline
\end{tabular}

Table 9 - The unfolding of the triple interaction between breed $\mathrm{x}$ incubator and values (averages) relating to Internal and external pip were derived by young $(y)$, middle-age $(\mathrm{m})$, old (o), cobb and ross breeders incubated in multiplestage (me) and single-stage (ss).

\begin{tabular}{ll}
\hline Internal and External Pip - Breed $x$ Incubator \\
\hline Interaction & Value of $p$ \\
Cobbxincubator & 0.0039 \\
\hline Cobb & \\
\hline Incubator & Averages \\
SS & $2.27^{\mathrm{A}}$ \\
ME & $0.88^{\mathrm{B}}$ \\
\hline
\end{tabular}

$A, B$ - Different capital letters in the columns indicate statistical difference by the Tukey test $(p<0.05)$; Equal letters not differ significantly between themselves.

\section{CONCLUSION}

The size of the eggs is related to the breeder's age and breed, which influences directly the number of bled eggs. Cobb eggs also need more attention because they are more sensitive to the low concentration of $\mathrm{CO}_{2}$ in the hacther. In addition, well-being in the hatchery can be improved by better management of eggs originating from the old breeders, mainly by thinking of improving hatching and reducing contamination. 
Oro CS, De Souza FEZ, Rodrigues WC, Oro JS, Guirro ECBP
Evaluation of the Relationship Between the Breeder's Age, Breed and the Incubator Types on Quality and Animal Welfare in the Hatchery

\section{REFERENCES}

Almeida JG, Dahlke F, Maiorka A, Faria Filho De, Oelke CA. Efeito da idade da matriz no tempo de eclosão, tempo de permanência do neonato no nascedouro e o peso do pintainho. Archives of Veterinary Science 2016;11(1):45-49.

Baião RC, Camargo LJ, Baião L, Baião N. Fatores que afetam a fertilidade de galos de matrizes pesadas [cited 2018 jan 13]. 2012. Available from: https://www.aviculturaindustrial.com.br/imprensa/fatores-que-afetama-fertilidade-de-galos-de-matrizes-pesadas/20160805-090939-H764.

Bamelis FR, Ketelaere B de, Mertens K. Kemps BJ, Decuypere EM, De Baerdemaeker JG. Measuring the conductance of eggshells using the acoustic resonance technique and optical transmission spectra. Computer Electronics Agriculture 2008;62:35-40.

Baracho MS, Nääs IA, Gigli ACS. Impacto das variáveis ambientais em incubatório de estágio múltiplo de frangos de corte. Engenharia Agrícola 2010;30(4):563-577.

Barbosa VM, Baião NC, Lara, LJC. Rocha JSR, Pompeu MA, Martins NRS, et al. Efeitos da umidade relativa do ar na incubação e da idade da matriz leve sobre a eclodibilidade, qualidade dos pintos recém-eclodidos e desempenho da progênie. Arquivo Brasileiro de Medicina Veterinária e Zootecnia 2015;67(3):882-890.

Campos JE. Avicultura razões, fatos e divergências. Incubação Industrial. Belo Horizonte: FEP-MVZ; 2000.

Carvalho FB, Strighini JH, Jardim Filho RM, Leandro NSM, Café MB, De Deus HASB. Qualidade interna e da casca para ovos de poedeiras comerciais de diferentes linhagens e idades. Ciência Animal Brasileira 2007;8:25-29.

Dos Santos ICB. Qualidade dos ovos incubáveis provenientes de matrizes pesadas de diferentes idades [dissertation]. Salvador (BA): Universidade Federal da Bahia; 2014.

Fernandes JIM, Contini JP, Scapini LB, Gurski TJ, Esser AFG, Dos Santos AL. Infuência da idade da matriz sobre a biometria de órgãos e a morfometria da mucosa do intestino delgado dos pintos na eclosão. Revistas Científicas de América Latina y el Caribe, España y Portugal 2016;35(2):1083

Gonzales E. Bem-estar animal no processo de incubação [cited 2018 october 12]. 2011. Available from: http://pt.engormix.com/MA-avicultura/ genetica/artigos/bem-estar-animal-incubacao-t603/103-p0.htm.

Hamidu JÁ, Fasenko GM, Feddes JJR, O'Dea EE, Ouellette CA, Wineland $\mathrm{MJ}$, et al. The effect of broiler breeder genetic strain and parent flock age on eggshell condutance and embryonic metabolism. Poultry Science 2007;86:2420-2432.
Marasco V, Robinson J, Herzyk P, Spencer KA. Pre and post-natal stress in context: effects on the stress physiology in a precocial bird. Journal of Experimental Biology 2012;215:3955-3964.

Molenaar R, Reijrink IAM, Meijerhof R, Van Der Brand H. meeting embryonic requirements of broilers throughout incubation: a review. Brazilian Journal of Poultry Science 2010;12(3):137-148.

O'dea EE, Fazenko GM, Feddes JJR, Robinson FE, Segura JC, Ouellette $C A$, et al. Investigating the eggshell condutance and embryonic metabolismo of modern and unselected domestic avian genetic strains at two flock ages. Poultry Science 2004;83:2059-2070.

Procksch FH, Freitas ES. Análise da mortalidade embrionária de acordo com a idade da matriz. Anais do $2^{\circ}$ Congresso Nacional de Medicina Veterinária FAG; 2018; Cascavel, Paraná. Brasil. Cascavel: Fundação Assis Gurgacz; 2018.

Rocha JSR, Lara LJC, Baião NC, Cançado SV, Baião LEC, Silva TR. Efeito da classificação dos ovos sobre o rendimento de incubação e os pesos do pinto e do saco vitelino. Arquivos Brasileiros de Medicina Veterinária e Zootecnia, Belo Horizonte 2008;60(4):979-986.

Rodricks CL, Miller SL, Jenkin G, Gibbs ME. The role of corticosterone in pre-hatch induced memory deficits in chicks. Brain Research 2006;1123:34-41.

Santos JEC, Gomes FS, Borges GLFN, Silva PL, Campos EJ, Fernandes EA, et al. Efeito da linhagem e da idade das matrizes na perda de peso dos ovos e no peso embrionário durante a incubação artificial. Biociência 2009;25 (1) 163-169.

Schmidt GS, Figueiredo EAP, Ávila VS. Incubação: característica dos ovos incubados [circular técnica 35]. Tamanduá: Embrapa Suínos e Aves, Embrapa Suínos e Aves; 2003. 12 p.

Silva MC, Noleto RA, Vaz RGMV, Costa ES, Sousa LF, Rodrigues KF, et al. Gravidade específica de ovos de matrizes pesadas com diferentes idades no rendimento de incubação e no peso dos pintos pós-eclosão. Revista Brasileira Saúde Produção Animal 2016;17(2):214-221.

Tanure CBGS, Café MB, Leandro NSM, Baião NC, Strighini JH, Gomes NA. Efeitos da idade da matriz leve e do período de armazenamento de ovos incubáveis no rendimento de incubação. Arquivo Brasileiro de Medicina Veterinária Zootecnia 2009;61:1391-1396. 
